\title{
Feasibility assessment of energy-neutral microalgae-based wastewater treatment plants under Spanish climatic conditions
}

Rubén Díez-Montero ${ }^{a^{*}}$, Alessandro Solimeno ${ }^{\mathrm{b}}$, Enrica Uggettia ${ }^{\mathrm{a}}$ María Jesús García-Galán ${ }^{\mathrm{a}}$, Joan García ${ }^{\mathrm{a}}$

${ }^{a}$ GEMMA - Group of Environmental Engineering and Microbiology, Department of Civil and Environmental Engineering, Universitat Politècnica de Catalunya - BarcelonaTech, c/ Jordi Girona 1-3, Building D1, E-08034, Barcelona, Spain

${ }^{b}$ Department of Chemical Engineering, University of Almeria, Ctra. Sacramento s/n, 04120 La Cañada de San Urbano, Almería, Spain

*Corresponding author. Email address: ruben.diez.montero@upc.edu (R. Díez-Montero)

\begin{abstract}
The energy balance of a hypothetical microalgae-based wastewater treatment plant (WWTP) has been performed for thirteen geographic locations covering the whole range of latitudes, longitudes and climate conditions of the different Spanish regions. The proposed WWTP includes high rate algae ponds (HRAPs) for secondary treatment and nitrogen removal, anaerobic codigestion of primary sludge and the biomass grown in the HRAPs, and a combined heat and power unit for electricity and heat production. The operation of the HRAPs was optimized using the BIO_ALGAE model, which also predicted the biomass production of the HRAPs under the different climate conditions. Under the assumptions of this study, the electrical energy balance resulted neutral or even positive in all the locations during the whole year, in spite of the climatic conditions variations. However, the heat balance resulted closer to the neutral footprint. The most favorable locations (Almeria and Seville, south of Spain) were analyzed in detail, confirming the feasibility of a positive electrical energy balance, while the heat balance resulted slightly negative in the cold season. Along with the solar radiation, the air temperature and its variation during the year are determinant to predict the feasibility of the heat balance in the proposed WWTP scheme.
\end{abstract}

\section{Keywords (maximum 6 keywords)}

Numerical simulations; Energy balance; Nature-based process; Low-cost wastewater treatment; Energy footprint; Anaerobic digestion 


\section{Introduction}

Microalgae-based wastewater treatment plants (WWTPs) are founded on the development of the interactions between microalgae and bacteria in order to remove pollutants from wastewater. Microalgae are photosynthetic organisms that produce oxygen and at the same time fix nutrients as well as solar energy in potentially valuable biomass. Aerobic bacteria use the produced oxygen to stabilize organic matter, achieving the objectives of secondary treatment, whereas they release carbon dioxide (through respiration) and nutrients (through degrading activity) needed for microalgae growth. This coupled microalgae-bacteria operation leads to a nature-based wastewater treatment system, with a very low energy consumption compared to conventional systems, since there is no need for electromechanical equipment for aeration.

During the last years, the search for alternative fuels to mitigate climate change has been one of the main driving forces boosting the interest in microalgae-based systems (Chisti, 2007), especially high rate algae ponds (HRAPs). HRAPs are outdoor open raceways that have been traditionally used in commercial production of microalgae and cyanobacteria, and also for wastewater treatment (Acién et al., 2016). These raceway ponds are closed-loop flow channels with a typical water depth of about 0.3-0.4 m, containing the mixed liquor (wastewater, microalgae and bacteria) which is constantly stirred, usually by means of slowly rotating paddlewheels. This mechanical stirring keeps the biomass in suspension and contributes to decrease light photosynthesis limitation, subsequently maximizing microalgae activity. Currently, biofuel production from microalgae is still price prohibitive, but the advantages of treating wastewater in HRAPs by means of mixed microalgae-bacteria cultures make this application highly attractive. Generally, and compared to conventional WWTPs, the estimated costs saving, including electrical power, is relevant enough to consider HRAPs for wastewater treatment independently from biofuels generation (Suganya et al., 2016).

In addition, anaerobic digestion of algal biomass along with settled wastewater solids (primary sludge) is an easy way to convert microalgae to biofuel (as biogas) and to recover nutrients from wastewater as a fertilizer after biofuel conversion (Craggs et al., 2014). All in all, characteristics such as the low energy consumption and production of a valuable biomass are of significant importance in order to achieve energy-neutral balance and self-sufficiency in WWTPs. By this approach, combining microalgae-based wastewater treatment in HRAPs and biogas production from the harvested biomass through anaerobic digestion, WWTPs can achieve a positive energy balance (Passos et al., 2017).

The performance of HRAPs is mainly influenced by the local irradiance and water temperature (Chisti, 2016), so that the geographic location of the microalgae-based WWTP has the greatest impact in biomass productivity and effluent quality (Dodd, 1986; Oswald, 1988); whereas the environmental temperature has a great impact in the energy requirements for maintaining anaerobic digesters at the desired temperature. Given the favorable climatic conditions of Spain, compared to those in other areas in Europe, it is expected that microalgae-based WWTPs could contribute to accomplish some of the current wastewater treatment challenges, such as providing an appropriate treatment to small and medium communities, upgrading existing facilities to implement nutrient removal or recovery, and reducing the energy consumption.

The objective of this study is to assess the feasibility of microalgae-based WWTPs from the energetic point of view under different Spanish climate conditions. To this aim, the energy balance of a hypothetical microalgae-based WWTP with anaerobic codigestion of harvested biomass and primary sludge has been assessed. The methodology previously presented by 
Passos et al. (2017) was complemented by applying advanced simulation modelling tools to predict the performance and the biomass productivity of the treatment plant. The model simulations and energy balance have been conducted in thirteen geographic locations in Spain, in order to evaluate the effect of the different climatic conditions. Furthermore, a sensitivity analysis has been performed in order to evaluate how the main input parameters may influence the results of the energy balance.

\section{Materials and methods}

\subsection{Plant setup and geographic locations}

A diagram of the proposed microalgae-based WWTP is shown in Figure 1. The treatment scheme consists of primary settling, HRAPs for biological treatment, secondary settling, and anaerobic codigestion of the harvested biomass and primary sludge. This scheme has been proposed aiming to achieve a neutral or positive energy balance, while accomplishing the desired effluent quality, based on: (i) nature based biological treatment with low energy demand; (ii) organic matter collection in a primary treatment in order to recover energy from wastewater and to reduce the organic loading to the biological process; and (iii) energy recovery unit to produce biofuel from the biomass and sludge. The hypothetical plant was dimensioned and designed according to the experimental results detailed below. This treatment scheme was used for the design and the energy balance assessment in the thirteen geographic locations. It is assumed that the hypothetical plant receives a constant wastewater flow rate of $1,500 \mathrm{~m}^{3} \mathrm{~d}^{-1}$, corresponding to an urban community of approximately 10,000 population equivalent (PE) in south Europe (Passos et al., 2017). It includes a conventional physical pretreatment, followed by two settling tanks (in parallel) for primary treatment, and four HRAPs (in parallel) for secondary treatment and nitrogen removal. Each HRAP has a volume of $3,000 \mathrm{~m}^{3}$ (total HRAP volume of $12,000 \mathrm{~m}^{3}$ ), corresponding to a hydraulic retention time (HRT) of 8 days. According to previous research, this is the highest HRT necessary in order to achieve standard secondary treatment requirements and nitrogen removal in winter in southern Europe (García et al., 2006, 2000). The depth of the HRAPs is assumed $0.4 \mathrm{~m}$ and the surface of each of them equals 0.75 ha. HRAPs are considered to have the typical shape of raceways with two channels and two reversals (469 $\mathrm{m}$ long and $8 \mathrm{~m}$ wide, each channel). Initially, and according to the experience gathered in southern Europe (Barcelona, Spain) only two of the four HRAPs would operate during the warm months (this means 4-days HRT, from April to September) (García et al., 2000). During the cold months (from October to March), 3 or 4 HRAPs would be operative (depending on the location), providing a 6-days or 8-days HRT, respectively. This operation strategy was optimized through mathematical simulations in order to provide a satisfactory effluent quality (see Section 2.2.).

The effluent from the HRAPs is clarified in two secondary settling tanks (in parallel), with the aid of coagulant addition in order to ensure a high biomass separation (Gutiérrez et al., 2016). Harvested biomass is then submitted to thickening, and it is pretreated in a thermal pretreatment unit at $75^{\circ} \mathrm{C}$ during $10 \mathrm{~h}$, as proposed by Passos and Ferrer (2014) and Passos et al. (2017), prior to the anaerobic digestion at $35^{\circ} \mathrm{C}$.

Primary sludge, collected in the primary settling tanks, is also submitted to thickening before being used as co-substrate in the anaerobic digestion. The total inflow to the digestion unit is therefore the sum of the biomass and primary sludge flows. The nominal volume of the anaerobic digester has been estimated considering the maximum monthly average of the total flow rate obtained during the year in each of the thirteen locations, and assuming a HRT of 20 
d. Consequently, the HRT in the remaining months results slightly higher, depending on the thickened biomass flow. The resulting anaerobic digester volume ranged from $320 \mathrm{~m}^{3}$ to $331 \mathrm{~m}^{3}$ in the thirteen scenarios. Finally, the produced biogas is conveyed to a combined heat and power (CHP) unit for electrical energy and heat production.

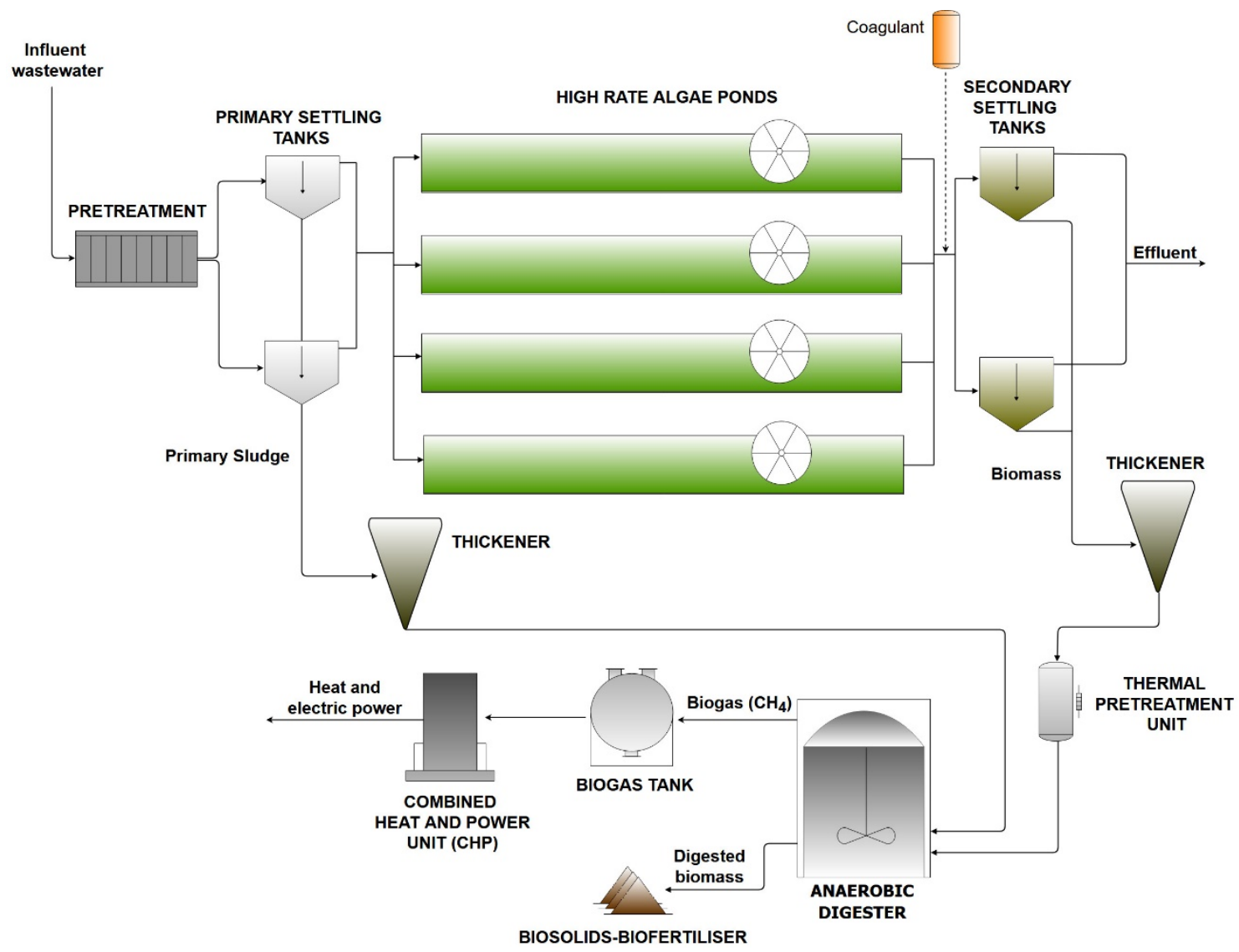

Figure 1. Treatment scheme of the hypothetical microalgae-based WWTP.

Regarding the geographic locations, thirteen cities have been selected covering the whole range of latitudes and longitudes of the Spain mainland. It should be noted that the hypothetical WWTPs are not aimed at being proposed as the treatment systems for such cities. The locations have been selected in order to cover the different environmental temperatures in the different Spanish regions, depending on factors such as the altitude, proximity to the coast, etc. A map showing the prevailing temperature in the different regions of Spain is presented in Figure 2, together with the selected geographic locations. These thirteen cities and their main climate conditions are presented in Table 1 and arranged according to the latitude (from North to South). The climate conditions have been obtained from the recordings of the Spanish Meteorology Bureau during the period 1981-2010 (AEMET, 2018). 


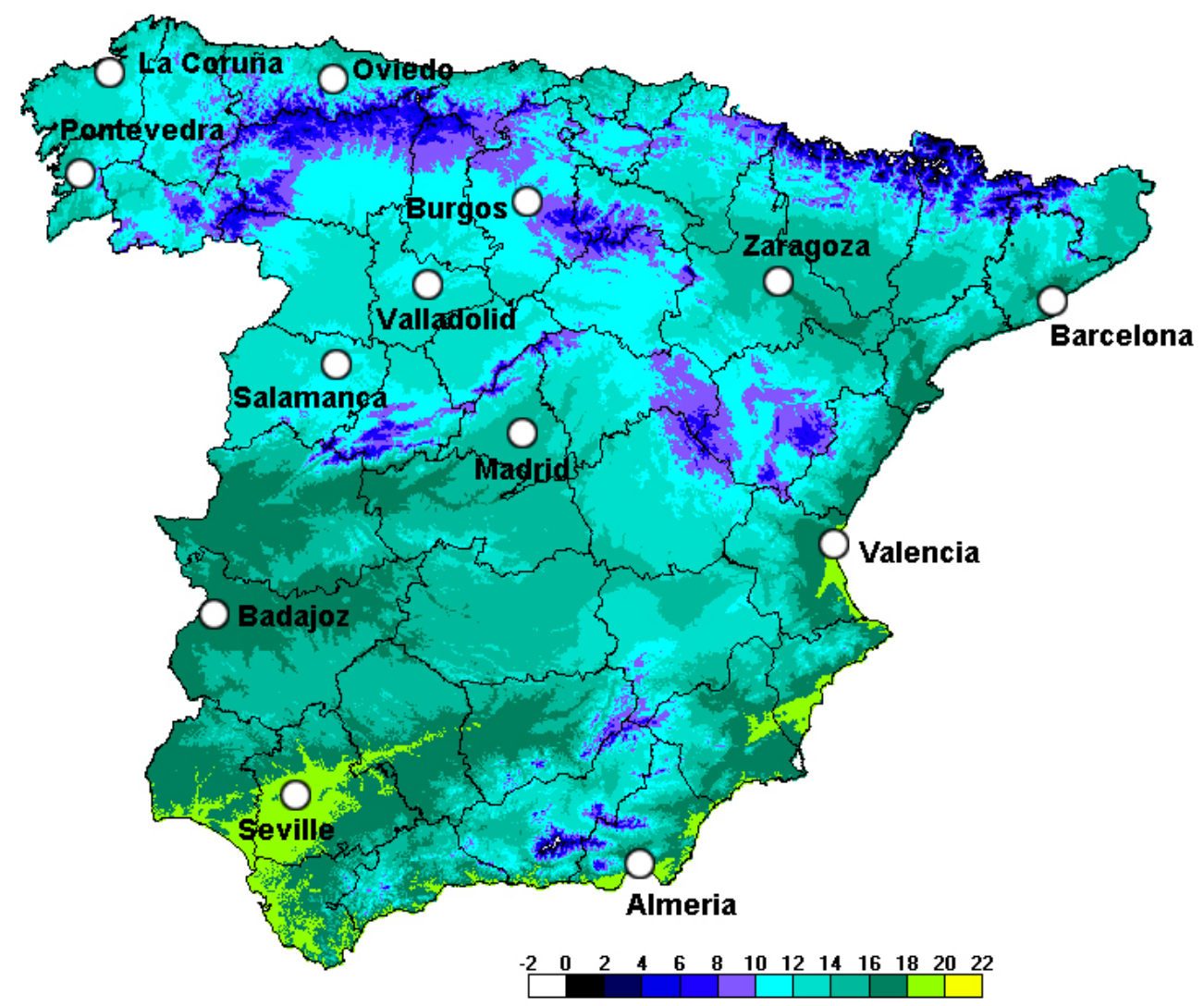

Figure 2. Spanish regions according to the annual average temperature $\left({ }^{\circ} \mathrm{C}\right)$ and selected geographic locations in this study (AEMET, 2018; Climaenmapas, 2018).

\begin{tabular}{llllll}
\hline Location & $\mathrm{T}\left({ }^{\circ} \mathrm{C}\right)$ & $\mathrm{T} \max \left({ }^{\circ} \mathrm{C}\right)$ & $\mathrm{Tmin}\left({ }^{\circ} \mathrm{C}\right)$ & $\mathrm{DR}$ & Latitude \\
\hline La Coruña & 14.8 & 19.6 & 10.8 & 129.6 & $43^{\circ} 21^{\prime} 57^{\prime \prime} \mathrm{N}$ \\
Oviedo & 13.3 & 19.1 & 8.3 & 122.3 & $43^{\circ} 21^{\prime} 12^{\prime \prime} \mathrm{N}$ \\
Pontevedra & 14.8 & 20.6 & 9.6 & 131.3 & $42^{\circ} 26^{\prime} 18^{\prime \prime} \mathrm{N}$ \\
Burgos & 10.7 & 19.5 & 3.1 & 83.5 & $42^{\circ} 21^{\prime} 25^{\prime \prime} \mathrm{N}$ \\
Zaragoza & 15.5 & 25.3 & 6.6 & 51.1 & $41^{\circ} 39^{\prime} 38^{\prime \prime} \mathrm{N}$ \\
Valladolid & 12.7 & 22.3 & 4.2 & 67.7 & $41^{\circ} 38^{\prime} 27^{\prime \prime} \mathrm{N}$ \\
Barcelona & 16.1 & 24.4 & 9.2 & 53.3 & $41^{\circ} 17^{\prime} 344^{\prime \prime} \mathrm{N}$ \\
Salamanca & 12.2 & 21.5 & 4.0 & 63.8 & $40^{\circ} 57^{\prime} 34 " \mathrm{~N}$ \\
Madrid & 14.5 & 25.2 & 5.5 & 55.1 & $40^{\circ} 28^{\prime} 00^{\prime \prime} \mathrm{N}$ \\
Valencia & 18.3 & 26.1 & 11.8 & 46.3 & $39^{\circ} 28^{\prime} 50^{\prime \prime} \mathrm{N}$ \\
Badajoz & 17.1 & 26.1 & 8.6 & 59.2 & $38^{\circ} 53^{\prime} 00^{\prime \prime} \mathrm{N}$ \\
Seville & 19.2 & 28.2 & 10.9 & 50.5 & $37^{\circ} 25^{\prime} 0 \mathrm{~N}$ \\
Almeria & 19.1 & 26.7 & 12.6 & 25.4 & $36^{\circ} 50^{\prime} 47^{\prime \prime} \mathrm{N}$ \\
\hline Tabl
\end{tabular}

Table 1. Name, latitude and main climate conditions of the thirteen geographic locations selected for this study (T: annual average temperature $\left({ }^{\circ} \mathrm{C}\right)$, Tmax: maximum monthly average temperature $\left({ }^{\circ} \mathrm{C}\right)$, Tmin: minimum monthly average temperature $\left({ }^{\circ} \mathrm{C}\right)$, DR: days per year with precipitation higher than $1 \mathrm{~mm}$ ).

\subsection{Simulation and optimization of plant operation and biomass production}

HRAPs operation and biomass production were simulated and optimized in the thirteen scenarios using the BIO_ALGAE model developed by Solimeno et al. (2017b). This model was 
conceived and implemented to understand the complexity of the internal functioning of microalgae-based WWTPs, and it allows to predict the removal efficiencies of organic matter and nutrients, as well as biomass production. BIO_ALGAE was mostly constructed coupling a microalgae model previously developed by Solimeno et al. $(2015,2016,2017 \mathrm{a})$ and the Activated Sludge Model ASM3 for bacteria-based wastewater treatment (Gujer et al., 1999). BIO_ALGAE was implemented in COMSOL Multiphysics ${ }^{\circledR}$ software, which solves the problem equations using the finite elements method (FEM). The model was calibrated and validated with experimental data from two pilot HRAPs with a water surface of $3.5 \mathrm{~m}^{2}$ in California (USA), which were fed with real municipal wastewater, as described in Solimeno et al. (2017b). In addition, prior to this study, further validation of the model was conducted using long-term experimental data from a pilot HRAP under climatic and operational conditions similar to those proposed in this study. The HRAP was located in Barcelona, with a water surface of $1.54 \mathrm{~m}^{2}$ and a volume of $0.47 \mathrm{~m}^{3}$, and it was operated at 4 and 8 days HRT treating municipal wastewater after primary treatment, as proposed in the treatment scheme of the present study. Validation was performed comparing measured data with simulation results in terms of $\mathrm{pH}$, dissolved oxygen, bicarbonate, ammonium $\left(\mathrm{NH}_{4}\right)$, nitrate, nitrite and total suspended solids (TSS) (Solimeno, 2017).

Simulations were performed assuming constant influent wastewater characteristics of primary treatment effluent: $\mathrm{pH}=7.68$; alkalinity $=400 \mathrm{mgCaCO}_{3} \mathrm{~L}^{-1} ; \mathrm{COD}=265 \mathrm{mgO}_{2} \mathrm{~L}^{-1} ; \mathrm{NH}_{4}=49$ $\mathrm{mgN} \mathrm{L}{ }^{-1}$; and $\mathrm{PO}_{4}=7.5 \mathrm{mgP} \mathrm{L} \mathrm{L}^{-1}$. These concentrations are the annual averages obtained experimentally in the pilot plant for long-term validation of the model (Solimeno, 2017). The initial concentrations of the mixed liquor were also those described in Solimeno (2017). Therefore, differences in biomass production in the thirteen scenarios are mostly due to operation (HRT) and climate conditions. Solar radiation at each scenario was calculated directly from a module available in BIO_ALGAE, which depends on Earth coordinates. Average monthly temperature data was obtained from local meteorological services. Water gains due to rain and losses due to evaporation were not considered, neither the decrease of solar radiation due to cloudiness, which effect is later discussed in Section 3.2. The monthly average biomass production in the thirteen locations was obtained from simulations. The biomass production includes microalgae and bacteria, but most of the biomass corresponds to microalgae $(>80 \%)$. More details are given in the work by Solimeno et al. (2017b).

In order to achieve the desired $\mathrm{NH}_{4}$ removal efficiency, the initial conditions of operation of the HRAPs are 8-4-8 days HRT, i.e. 8-days HRT from January to March, 4-days HRT from April to September, and 8-days HRT from October to December, according to the results of previous research carried out in Barcelona (García et al., 2000). As a general rule, we considered that operation is suitable when the concentration of $\mathrm{NH}_{4}$ in the effluent is lower than $10 \mathrm{mgN} \mathrm{L}^{-1}$, in order to fulfil the total nitrogen European standard (European Union, 2000, 1991). $\mathrm{NH}_{4}$ was selected as performance indicator because it is very sensitive to changes in the environmental conditions in HRAPs, while other nitrogen species are not as noteworthy as $\mathrm{NH}_{4}$ in these systems. Thus, the $\mathrm{NH}_{4}$ concentration in the effluent was checked in the thirteen locations and the HRT was consequently reduced from 8 days (4 HRAPs in operation) to 6 days (3 HRAPs in operation) in those cases where the climate conditions led to a better performance, specifically Valencia, Seville and Almeria. The operation strategy in the remaining ten locations (La Coruña, Oviedo, Pontevedra, Burgos, Zaragoza, Valladolid, Barcelona, Salamanca, Madrid and Badajoz) was eventually 8-4-8 days HRT. It should be considered that lower HRTs mean more optimized systems, meaning that less energy is required for operation as less HRAPs units are needed. 


\subsection{Energy balance}

The energy balance was performed according to the methodology presented by Passos et al. (2017). In brief, energy inputs (consumption) and output (production) were estimated and net energy ratios of electricity and heat were obtained considering the features and assumptions described below. Details on parameters and values used for the energy assessment are summarized in Table 2. Formulas and calculations are also presented in the following sections. Compared to the original work by Passos et al. (2017), in this study the energy consumption of other process units (pretreatment, settling and thickening) has been included, the biomass flow rate has been obtained from the biomass production in the HRAPs (predicted by mathematical model simulations), and the primary sludge flow rate has been obtained according to the influent wastewater characteristics and the settling efficiency. As in the work by Passos et al. (2017), a CHP unit is assumed to generate both heat and electricity from biogas. The energy balance was conducted over a monthly basis in order to consider mean changes in environmental conditions (mostly solar radiation and temperature). A more detailed evaluation (e.g. daily) is out of the scope of this feasibility assessment, in order to keep a balance between complexity and results reliability. 


\begin{tabular}{|c|c|c|c|}
\hline Parameter & Unit & Value & Reference \\
\hline WWTP capacity & $\mathrm{PE}$ & 10,000 & This study \\
\hline Wastewater generation & $L \mathrm{PE}^{-1} \mathrm{~d}^{-1}$ & 150 & This study \\
\hline Wastewater flow rate $(\mathrm{Q})$ & $\mathrm{m}^{3} \mathrm{~d}^{-1}$ & 1,500 & This study \\
\hline \multicolumn{4}{|l|}{$\begin{array}{l}\text { input,electricity HRAP } \\
\end{array}$} \\
\hline Number of HRAP & - & $2-3-4$ & $\begin{array}{l}\text { Optimized by } \\
\text { simulations }\end{array}$ \\
\hline Channel width (W) & $\mathrm{m}$ & 8 & Calculated \\
\hline Channel length (L) & $\mathrm{m}$ & 469 & Calculated \\
\hline HRAP unit surface area (A) & $\mathrm{m}^{2}$ & 7,500 & Calculated \\
\hline Water depth (d) & $\mathrm{m}$ & 0.4 & $\begin{array}{l}\text { (Sutherland et al., } \\
\text { 2014) }\end{array}$ \\
\hline Water velocity (v) & $\mathrm{m} \mathrm{s}^{-1}$ & 0.15 & $\begin{array}{l}\text { (Lundquist et al., } \\
\text { 2010) }\end{array}$ \\
\hline Water flow rate in motion $\left(\mathrm{Q}_{\mathrm{w}}\right)$ & $\mathrm{m}^{3} \mathrm{~s}^{-1}$ & 0.48 & Calculated \\
\hline Manning friction factor (n) & - & 0.025 & $\begin{array}{l}\text { (Lundquist et al., } \\
\text { 2010) }\end{array}$ \\
\hline Specific weight of water at $20^{\circ} \mathrm{C}(\gamma)$ & $\mathrm{kN} \mathrm{m}^{-3}$ & 9.78 & $\begin{array}{l}\text { (Tchobanoglous et al., } \\
2003 \text { ) }\end{array}$ \\
\hline Paddlewheel efficiency $(\varepsilon)$ & $\%$ & 30 & $\begin{array}{l}\text { (Lundquist et al., } \\
\text { 2010) }\end{array}$ \\
\hline \multicolumn{4}{|l|}{$\mathbf{E}_{\text {input,electricity other units }}$} \\
\hline Specific power consumption $\left(\mathrm{SPC}_{\mathrm{OU}}\right)$ & $\mathrm{kWh} \mathrm{m}^{-3}$ & 0.06 & (Ferrer, 2012) \\
\hline \multicolumn{4}{|l|}{$\mathbf{E}_{\text {input,electricity AD }}$} \\
\hline Digester hydraulic retention time $\left(\mathrm{HRT}_{\mathrm{d}}\right)$ & day & $20.0-26.2$ & Calculated \\
\hline Digester nominal volume $\left(\mathrm{V}_{\mathrm{d}}\right)$ & $\mathrm{m}^{3}$ & $320-331$ & Calculated \\
\hline Energy consumption for pumping $(\theta)$ & $\mathrm{kJ} \mathrm{m}^{-3}$ & 1,800 & (Lu et al., 2008) \\
\hline Energy consumption rate for mixing $(\omega)$ & $\mathrm{kJ} \mathrm{m}^{-3} \mathrm{~d}^{-1}$ & 300 & (Lu et al., 2008) \\
\hline Thickened microalgal biomass VSS concentration $\left(\mathrm{VSS}_{\mathrm{mb}}\right)$ & $\mathrm{kgVSS} \mathrm{m}^{-3}$ & 25 & This study \\
\hline Thickened primary sludge VSS concentration $\left(\mathrm{VSS}_{\mathrm{ps}}\right)$ & $\mathrm{kgVSS} \mathrm{m}^{-3}$ & 28.5 & This study \\
\hline Microalgal biomass harvesting efficiency $(\varphi)$ & - & 0.9 & (Gutiérrez et al., 2016) \\
\hline Primary settling efficiency $(\eta)$ & - & 0.5 & This study \\
\hline \multicolumn{4}{|l|}{ Einput,heat AD } \\
\hline Density of digester influent ( $\rho$ ) & $\mathrm{kg} \mathrm{m}^{-3}$ & 1,000 & $\begin{array}{l}\text { (Tchobanoglous et al., } \\
\text { 2003) }\end{array}$ \\
\hline Specific heat of digester influent $(\gamma)$ & $\mathrm{kJ} \mathrm{kg}^{-1}{ }^{\circ} \mathrm{C}^{-1}$ & 4.18 & $\begin{array}{l}\text { (Tchobanoglous et al., } \\
\text { 2003) }\end{array}$ \\
\hline Ambient temperature $\left(\mathrm{T}_{\mathrm{a}}\right)$ & ${ }^{\circ} \mathrm{C}^{-1}$ & $3.1-28.2$ & This study \\
\hline Anaerobic digestion temperature $\left(\mathrm{T}_{\mathrm{d}}\right)$ & ${ }^{\circ} \mathrm{C}^{-1}$ & 35 & This study \\
\hline Pretreatment temperature $\left(T_{p}\right)$ & ${ }^{\circ} \mathrm{C}^{-1}$ & 75 & $\begin{array}{l}\text { (Passos and Ferrer, } \\
\text { 2014) }\end{array}$ \\
\hline Heat transfer coefficient $(\mathrm{k})$ & $\mathrm{W} \mathrm{m}{ }^{-2}{ }^{\circ} \mathrm{C}^{-1}$ & 1 & $\begin{array}{l}\text { (Tchobanoglous et al., } \\
\text { 2003) }\end{array}$ \\
\hline Heat recovery efficiency $(\phi)$ & - & 0.85 & (Lu et al., 2008) \\
\hline \multicolumn{4}{|l|}{$\mathbf{E}_{\text {output }}$} \\
\hline Lower heating value of methane $(\xi)$ & $\mathrm{kWh} \mathrm{m}^{-3} \mathrm{CH}_{4}$ & 10 & $\begin{array}{l}\text { (Tchobanoglous et al., } \\
\text { 2003) }\end{array}$ \\
\hline Methane yield (Y) & $\begin{array}{l}\mathrm{m}^{3} \mathrm{CH}_{4} \\
\mathrm{~kg}^{-1} \text { VSS }\end{array}$ & 0.25 & (Solé et al., 2015) \\
\hline Electricity generation efficiency of the CHP unit $(\eta 1)$ & - & 0.35 & Assumed \\
\hline Heat generation efficiency of the CHP unit ( $\eta 2)$ & - & 0.55 & Assumed \\
\hline
\end{tabular}

Table 2. Parameters used for the energy assessment of the microalgae-based WWTPs. 


\subsubsection{Energy input}

The energy inputs (consumption) included in this study were: (1) electricity for the HRAPs paddlewheels; (2) electricity for other process units (pretreatment, settling and thickening); and (3) electricity and heat for the anaerobic digester.

The electricity input for the paddlewheels in a single HRAP was calculated from Eq. (1) (Lundquist et al., 2010).

$$
\mathrm{E}_{\text {input,electricity HRAP }}=\frac{\mathrm{Q}_{\mathrm{W}} \cdot \gamma \cdot\left(\Delta \mathrm{d}_{\text {channels }}+\Delta \mathrm{d}_{\text {reversals }}\right) \cdot 24}{A \cdot \varepsilon}
$$

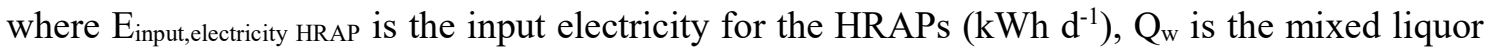
flow rate in motion $\left(\mathrm{m}^{3} \mathrm{~s}^{-1}\right), \gamma$ is the specific weight of water at $20^{\circ} \mathrm{C}\left(\mathrm{kN} \mathrm{m}^{-3}\right), \Delta \mathrm{d}_{\text {reversals }}$ is the head loss in reversals $(\mathrm{m}), \Delta \mathrm{d}_{\text {channels }}$ is the head loss in channels $(\mathrm{m})$, A is HRAPs surface area $\left(\mathrm{m}^{2}\right)$ and $\varepsilon$ is the paddlewheel efficiency.

The flow rate of mixed liquor in motion $\left(\mathrm{Q}_{\mathrm{w}}\right)$ was determined according to the water velocity within the HRAPs (Eq. (2)).

$$
\mathrm{Q}_{\mathrm{w}}=\mathrm{u} \cdot \mathrm{d} \cdot \mathrm{W}
$$

where $v$ is the water velocity $\left(\mathrm{m} \mathrm{s}^{-1}\right), \mathrm{d}$ is the water depth $(\mathrm{m})$ and $\mathrm{W}$ is the channel width (m).

The head losses in channels and reversals were calculated according to Eq. (3) and (4), respectively (Lundquist et al., 2010).

$$
\Delta \mathrm{d}_{\text {channels }}=\frac{\mathrm{v}^{2} \cdot \mathrm{L}}{\left(\frac{1.428}{\mathrm{n}}\right)^{2} \cdot\left(\frac{\mathrm{d} \cdot \mathrm{W}}{\mathrm{W}+2 \cdot \mathrm{d}}\right)^{1.26}}
$$

where $\Delta \mathrm{d}_{\text {channels }}$ is head loss in channels (m), L is the channel length (m) and $\mathrm{n}$ is the Manning friction factor.

$$
\Delta \mathrm{d}_{\text {reversals }}=2 \cdot \frac{v^{2}}{2 \cdot g}
$$

where $\Delta \mathrm{d}_{\text {reversals }}$ is the head loss in reversals ( $\left.\mathrm{m}\right)$ and $\mathrm{g}$ is the gravitational force $\left(\mathrm{m} \mathrm{s}^{-2}\right)$.

Finally, the unit electricity input was multiplied by the number of HRAPs operating in each period (two from April to September, and three or four from October to March, depending on the location).

The energy required for other process units (pretreatment, settling and thickening) was calculated according to Eq. (5).

$$
\mathrm{E}_{\text {input,electricity other units }}=\mathrm{Q} \cdot S P C_{O U}
$$

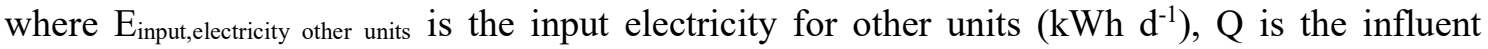
wastewater flow rate $\left(\mathrm{m}^{3} \mathrm{~d}^{-1}\right)$ and $\mathrm{SPC}_{\mathrm{OU}}$ is the specific power consumption of other units $(\mathrm{kWh}$ $\mathrm{m}^{-3}$ ), which was adopted from data of specific treatment units from Spanish WWTPs (Ferrer, 2012).

Regarding the anaerobic digestion, the energy required included: (1) electricity for pumping and mixing; and (2) heat for pretreatment of biomass and codigestion of biomass and primary sludge. The electricity input was calculated according to (Eq. (6)).

$$
\mathrm{E}_{\text {input,electricity AD }}=\left(\left(\mathrm{Q}_{\mathrm{mb}}+\mathrm{Q}_{\mathrm{ps}}\right) \cdot \theta+V_{d} \cdot \omega\right) \cdot 0.000278
$$


where $E_{\text {inputelectricity }} \mathrm{AD}$ is the input electricity for anaerobic digestion $\left(\mathrm{kWh} \mathrm{d}^{-1}\right) ; \mathrm{Q}_{\mathrm{mb}}$ is the thickened microalgal biomass flow rate $\left(\mathrm{m}^{3} \mathrm{~d}^{-1}\right)$; $\mathrm{Q}_{\mathrm{ps}}$ is the thickened primary sludge flow rate $\left(\mathrm{m}^{3} \mathrm{~d}^{-1}\right) ; \Theta$ is the electricity consumption for pumping $\left(\mathrm{kJ} \mathrm{m}^{-3}\right)$ ( $\mathrm{Lu}$ et al., 2008); $\mathrm{V}_{\mathrm{d}}$ is the digester nominal volume $\left(\mathrm{m}^{3}\right)$; $\omega$ is the electricity consumption for mixing $\left(\mathrm{kJ} \mathrm{m}^{-3} \mathrm{~d}^{-1}\right)(\mathrm{Lu}$ et al., 2008); and 0.000278 is the conversion factor from $\mathrm{kJ}$ to $\mathrm{kWh}$.

The microalgal biomass flow rate $\mathrm{Q}_{\mathrm{mb}}$ and primary sludge flow rate were calculated according to Eq. (7) and Eq. (8), respectively.

$$
\mathrm{Q}_{\mathrm{mb}}=\frac{\mathrm{B}_{\mathrm{p}} \cdot \mathrm{A} \cdot \varphi}{\mathrm{VSS}_{\mathrm{mb}}}
$$

where $\mathrm{Q}_{\mathrm{mb}}$ is the thickened microalgal biomass flow rate $\left(\mathrm{m}^{3} \mathrm{~d}^{-1}\right) ; \mathrm{B}_{\mathrm{p}}$ is the microalgal biomass production ( $\left(\mathrm{gVSS} \mathrm{m} \mathrm{m}^{-2} \mathrm{~d}^{-1}\right) ; \varphi$ is the biomass harvesting efficiency; and $\mathrm{VSS}_{\mathrm{mb}}$ is the thickened microalgal biomass volatile solids concentration $\left(\mathrm{gVSS} \mathrm{m}^{-3}\right)$.

$$
\mathrm{Q}_{\mathrm{ps}}=\frac{\mathrm{Q} \cdot \mathrm{VSS}_{\mathrm{inf}} \cdot \eta}{\mathrm{VSS}_{\mathrm{ps}} \cdot 1000}
$$

where $Q_{p s}$ is the thickened primary sludge flow rate $\left(\mathrm{m}^{3} \mathrm{~d}^{-1}\right)$; VSS $\mathrm{Sin}_{\text {in }}$ is the influent wastewater VSS concentration $\left(m g V S S L^{-1}\right) ; \eta$ is the primary settling efficiency; and $\mathrm{VSS}_{\mathrm{ps}}$ is the thickened primary sludge VSS concentration ( $\left.\mathrm{gVSS} \mathrm{L}^{-1}\right)$.

The heat input for the anaerobic digestion was calculated as the energy required for heating the influent microalgal biomass from ambient temperature $\left(T_{a}\right)$ to the pretreatment temperature $\left(T_{p}\right)$, and subtracting the energy recovered by cooling down the biomass from the pretreatment temperature $\left(T_{p}\right)$ to the digestion temperature $\left(T_{d}\right)$. Besides, the heat requirement for rising up primary sludge temperature from $T_{a}$ to $T_{d}$ was also accounted for Eq. (9).

$$
\begin{aligned}
& E_{\text {input,heat } A D}=\left[\rho \cdot \mathrm{Q}_{\mathrm{mb}} \cdot \gamma \cdot\left(\mathrm{T}_{\mathrm{p}}-\mathrm{T}_{\mathrm{a}}\right)-\rho \cdot \mathrm{Q}_{\mathrm{mb}} \cdot \gamma \cdot\left(\mathrm{T}_{\mathrm{p}}-\mathrm{T}_{\mathrm{d}}\right) \cdot \phi+\rho \cdot \mathrm{Q}_{\mathrm{ps}} \cdot \gamma \cdot\right. \\
& \left.\left(\mathrm{T}_{\mathrm{d}}-\mathrm{T}_{\mathrm{a}}\right)+\mathrm{k} \cdot \mathrm{A}_{\mathrm{d}} \cdot\left(\mathrm{T}_{\mathrm{d}}-\mathrm{T}_{\mathrm{a}}\right) \cdot 86.4\right] \cdot 0.000278
\end{aligned}
$$

where $E_{\text {inputheat }} \mathrm{AD}$ is the input heat for the anaerobic digestion with microalgal biomass pretreatment $\left(\mathrm{kWh} \mathrm{d}^{-1}\right) ; \rho$ is the digester influent density $\left(\mathrm{kg} \mathrm{m}^{-3}\right) ; \gamma$ is the digester influent specific heat $\left(\mathrm{kJ} \mathrm{kg}^{-1}{ }^{\circ} \mathrm{C}^{-1}\right) ; \mathrm{T}_{\mathrm{p}}$ is the pretreatment temperature $\left({ }^{\circ} \mathrm{C}\right) ; \mathrm{T}_{\mathrm{a}}$ is the air temperature $\left({ }^{\circ} \mathrm{C}\right) ; \mathrm{T}_{\mathrm{d}}$ is the anaerobic digestion temperature $\left({ }^{\circ} \mathrm{C}\right) ; \phi$ is the heat recovery efficiency; $\mathrm{k}$ is the heat transfer coefficient $\left(\mathrm{W} \mathrm{m}^{-2}{ }^{\circ} \mathrm{C}^{-1}\right)$; $\mathrm{A}_{\mathrm{d}}$ is the surface area of the digester wall $\left(\mathrm{m}^{2}\right)$; and 0.000278 is the conversion factor from $\mathrm{kJ}$ to $\mathrm{kWh}$.

\subsubsection{Energy output}

Energy is produced from methane $\left(\mathrm{CH}_{4}\right)$ derived from the biomass codigestion with primary sludge. Experimental studies on microalgae biomass codigestion have given $\mathrm{CH}_{4}$ yield values up to $0.46 \mathrm{~m}^{3} \mathrm{CH}_{4} \mathrm{kgVSS}^{-1}$, but with great variation depending on the biomass/sludge ratio (Solé et al., 2015; Uggetti et al., 2017). For this reason, a conservative value of $0.25 \mathrm{~m}^{3} \mathrm{CH}_{4} \mathrm{kgVSS}^{-1}$ is assumed to evaluate $\mathrm{CH}_{4}$ production.

The electricity output was calculated from the average methane yield (Eq. (10)). A lower calorific value of methane ( $\xi$ ) of $10 \mathrm{kWh} \mathrm{m}^{-3} \mathrm{CH}_{4}$ (Tchobanoglous et al., 2003) and an electricity conversion efficiency of the CHP unit of $35 \%$ were considered $\left(\eta_{1}\right)$.

$$
\mathrm{E}_{\text {output,electricity }}=\left(\mathrm{P}_{\mathrm{b}} \cdot \mathrm{Y} \cdot \xi \cdot \eta_{1}\right)
$$

where $\mathrm{E}_{\text {output,electricity }}$ is the output electricity from biogas $\left(\mathrm{kWh} \mathrm{d}^{-1}\right)$; $\mathrm{P}_{\mathrm{b}}$ is the VSS production with which the digester is fed $\left(\mathrm{kgVSS} \mathrm{d}^{-1}\right)$ (microalgae biomass production plus primary sludge 
production); $\mathrm{Y}$ is the average methane yield $\left(\mathrm{m}^{3} \mathrm{CH}_{4} \mathrm{kgVSS}^{-1}\right)$; $\xi$ is the lower calorific value of methane $\left(\mathrm{kWh} \mathrm{m}^{-3} \mathrm{CH}_{4}\right)$; and $\eta_{1}$ is the efficiency for electricity generation.

Regarding the heat output, it was calculated according to Eq. (11). The heat conversion efficiency $\left(\eta_{2}\right)$ was assumed to be $55 \%$ in the CHP unit.

$$
\mathrm{E}_{\text {output,heat }}=\left(\mathrm{P}_{\mathrm{b}} \cdot \mathrm{Y} \cdot \xi \cdot \eta_{2}\right)
$$

where $E_{\text {outputheat }}$ is the output heat from biogas $\left(\mathrm{kWh} \mathrm{d}^{-1}\right)$; and $\eta_{2}$ is the efficiency for heat generation.

\subsubsection{Net energy ratio}

Finally, the net energy ratio (NER) of electricity (NER electricity) and heat (NER heat) were calculated as the energy output (production) divided by the energy input (consumption) according to (Eq. (12) and (13)). It should be noted that values higher than 1 indicate net energy production.

$N E R_{\text {electricity }}=\frac{\mathrm{E}_{\text {output,electricity }}}{\mathrm{E}_{\text {input,electricity HRAP }}+\mathrm{E}_{\text {input,electricity other units }}+\mathrm{E}_{\text {input,electricity AD }}}$

$$
N E R_{\text {heat }}=\frac{\mathrm{E}_{\text {output,heat }}}{\mathrm{E}_{\text {input,heat } \mathrm{AD}}}
$$

The NER of the thirteen locations were evaluated on yearly, seasonal and monthly basis.

\subsection{Sensitivity analysis}

In the work by Passos et al. (2017) a sensitivity analysis was performed to evaluate how the uncertainty on input parameters may influence the results of the energy balance in microalgae-based WWTPs. The most sensitive parameters were the heat transfer coefficient $(\mathrm{k})$ and the heat recovery efficiency $(\phi)$. Therefore, the sensitivity of both parameters has been considered and analyzed in the application to the new case scenarios.

However, it should be noticed that both parameters have only effect on the heat balance, so additional parameters affecting the electrical energy balance have been included in the sensitivity analysis, specifically, the specific power consumption of other units ( $\left.\mathrm{SPCOU}_{\mathrm{O}}\right)$ and the efficiency in primary settling $(\eta)$.

Regarding the SPCou, since the HRAPs energy consumption is low, the energy consumption of other units could have a greater effect in the overall energy balance compared to conventional WWTPs (in relation with the secondary treatment). The sensitivity analysis of the SPCou could elucidate if it is worth it to focus efforts on reducing the energy consumption of those other units. Regarding $\eta$, this upgrade of the methodology estimates the amount of sludge actually collected in the primary settling tanks, which will be codigested with the microalgae-bacteria biomass. For this reason, $\eta$ will have an effect on the total amount of sludge to be digested, and consequently on the amount of produced biogas.

The sensitivity analysis has been performed determining and comparing the $\mathrm{NER}_{\text {electricity }}$ and $\mathrm{NER}_{\text {heat }}$ for three different values of the analyzed parameters. Parameter values have been increased and reduced $25 \%$ and compared to the results obtained with the initial value, except $\phi$, which was increased and reduced only $18 \%$ in order to avoid an inconsistent use of efficiency 
higher than 100\%. Additionally, the sensitivity function (absolute-relative) of the four parameters has also been analyzed, and it is presented as Supplementary Material.

\section{Results and discussion}

\subsection{Performance of the microalgae-based wastewater treatment: ammonium removal and biomass production}

The effluent concentrations of $\mathrm{NH}_{4}$ (in fact, $\mathrm{NH}_{4}{ }^{+}+\mathrm{NH}_{3}$ ) obtained in the simulations of the microalgae-based WWTP in the thirteen geographical locations are shown in Figure 3. Very low and similar $\mathrm{NH}_{4}$ concentrations were achieved during the whole year in all the analyzed locations, except in January, when concentration peak appears in Salamanca and Valladolid, and December, when the highest peak in Seville is observed. These peaks are attributed to the lower temperature and solar radiation during these two months, and to the operation strategy: Salamanca and Valladolid are locations with two of the lowest monthly average minimum temperatures; whereas Seville is the location with the lowest monthly average minimum temperature, among the locations with only 6-days HRT in winter (Almeria, Valencia and Seville) (see Table 1). Nevertheless, these peaks are not found during the rest of the year, keeping low annual average ammonium concentrations in all the locations. It should be taken into account that the annual mean total nitrogen concentration is the parameter which shall conform the European standards.

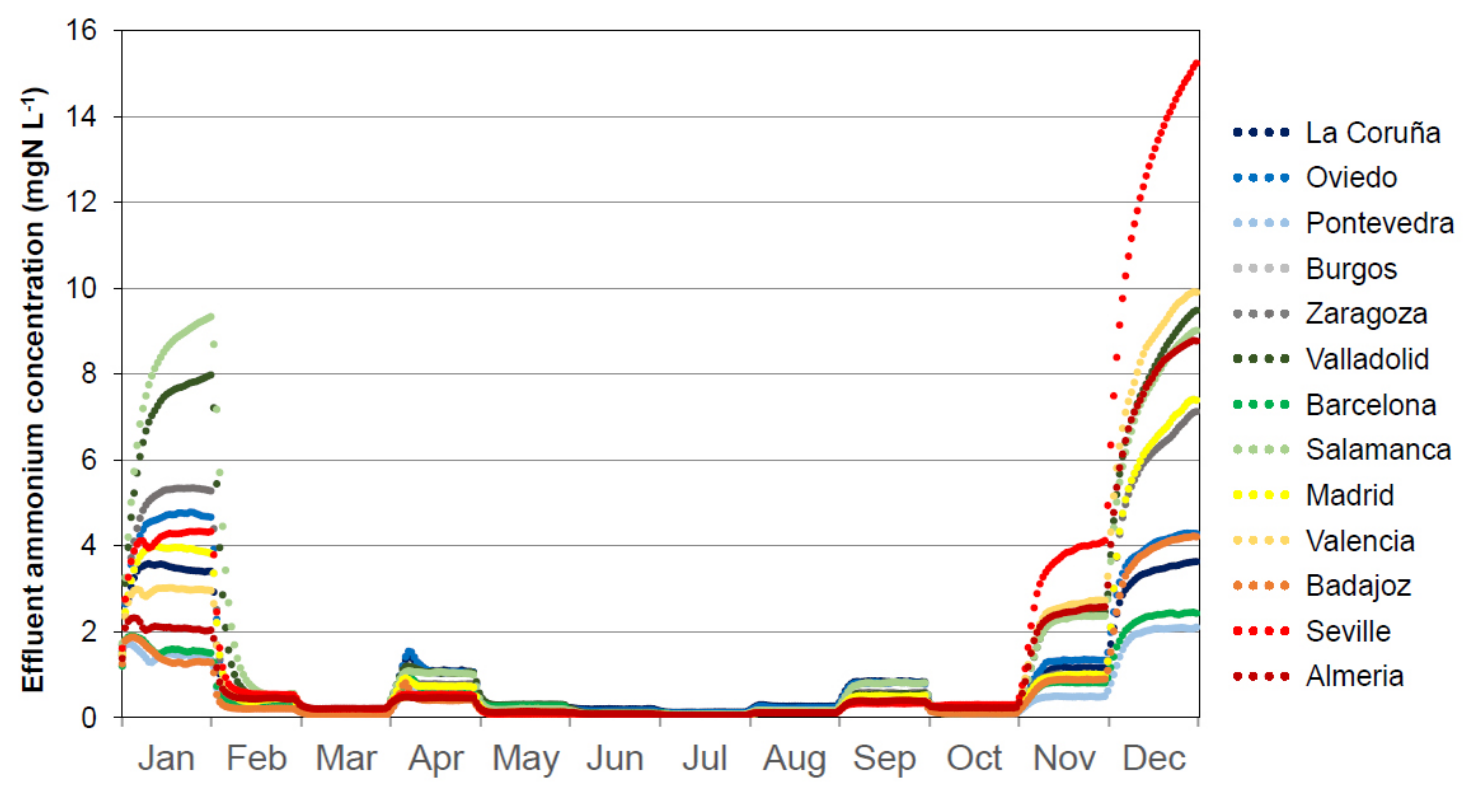

Figure 3. Daily average effluent ammonium concentration $\left(\mathrm{mgN} \mathrm{L}^{-1}\right)$ in the simulations of the thirteen locations, according to simulations with BIO_ALGAE model.

Daily average TSS concentrations in the HRAPs in the thirteen locations are shown in Figure 4, while the average monthly specific biomass productions are depicted in Figure 5. Biomass concentrations around 300-350 $\mathrm{mgTSS} \mathrm{L}^{-1}$ were obtained in all the locations, except some lower values observed in January and December, again in Salamanca, Valladolid and Seville, in accordance with the $\mathrm{NH}_{4}$ concentration results. Regarding the specific biomass production, simulated results ranged between 10.9 and $29.9 \mathrm{gTSS} \mathrm{m}^{-2} \mathrm{~d}^{-1}$. These results are in agreement with reported experimental results obtained in pilot-industrial HRAPs treating wastewater (10-35 gTSS m$^{-2} \mathrm{~d}^{-1}$ ) (Hoffmann, 1998), and in pilot HRAPs under Spanish climatic conditions: 
6-33 gTSS m$^{-2} \mathrm{~d}^{-1}$ in Barcelona (García et al., 2006). The highest specific biomass productions were obtained during the warm period, while significantly lower values were obtained during the cold period. This is mainly due to the number of HRAPs in operation. In spite of the specific biomass production variations, , the biomass concentration is quite stable during the whole year due to the variation of the HRT, resulting only in slightly lower values during the cold period than in the warm period. The similarity in the biomass production between the different locations is attributed to the fact that, even though the selected locations cover the whole range of latitudes in the Spain mainland, the latitudes of all of them are actually similar.

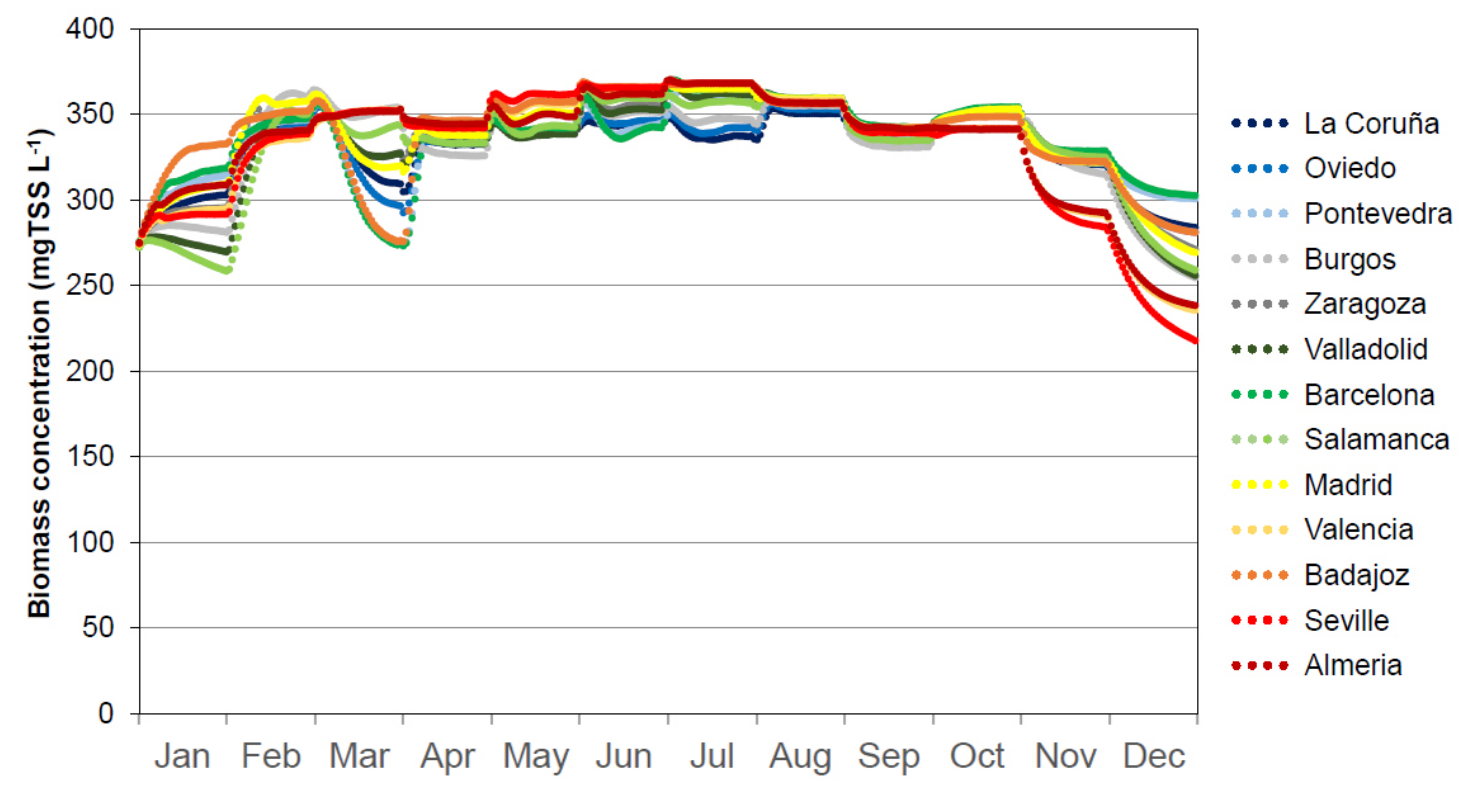

Figure 4. Daily average biomass concentration $\left(\mathrm{mgTSS} \mathrm{L}^{-1}\right)$ in the simulations of the thirteen locations, according to simulations with BIO_ALGAE model during a year. 


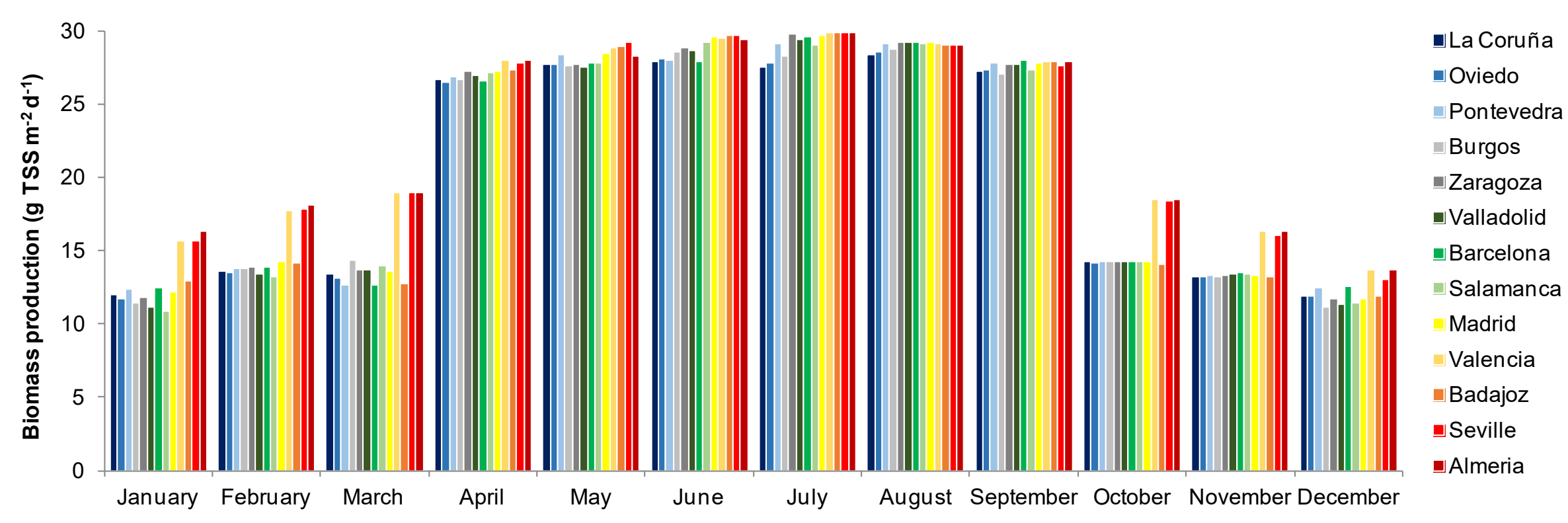

Figure 5. Average monthly specific biomass production $\left(\mathrm{gTSS} \mathrm{m}^{-2} \mathrm{~d}^{-1}\right)$ derived from TSS concentration in the thirteen geographic locations, according to simulations with BIO_ALGAE model during a year period (8-4-8 days HRT in all locations, except Valencia, Seville and Almeria, 6-4-6 days HRT). 


\subsection{Annual overall energy and heat balance}

The annual average $\mathrm{NER}_{\text {electricity }}$ and $\mathrm{NER}_{\text {heat }}$ values are presented in Figure 6 together with the corresponding standard deviations (SD). It should be noted that in this study the SD represents the variability within the year period, in a monthly basis. It can be observed that NER electricity is clearly over 1 (in fact, higher than 2.3) in all the locations, suggesting that the energy balance is largely positive. The differences between NER $_{\text {electricity }}$ in the different locations are almost negligible, which is attributed to the similar biomass production in all the locations, as described in Section 3.1. In addition, NER electricity fluctuations during the year are not highly noticeable, according to the low SD observed in Figure 6, suggesting that the feasibility of the positive energy balance can be achieved during the whole year, in spite of the climate conditions variations.

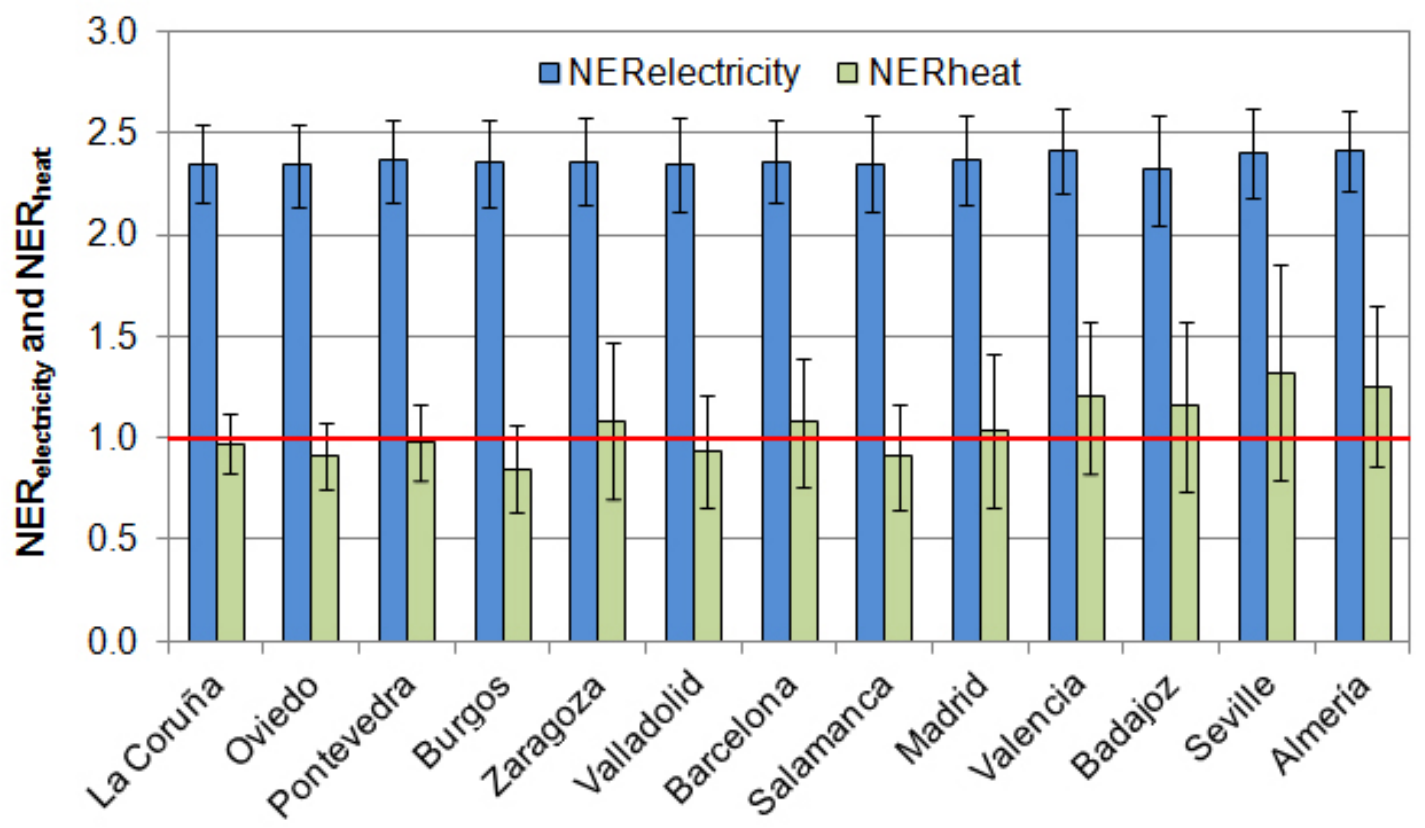

Figure 6. Results of the net energy ratio (NER) assessment for the microalgae-based WWTP in the thirteen locations $\left(\mathrm{NER}_{\text {electricity }}\right.$ and $\mathrm{NER}_{\text {heat, }}$ annual average $\left.\pm \mathrm{SD}\right)$.

However, NER heat values are much closer to the neutral value (average values between 0.85 and 1.32), with noticeable differences between the different locations. Annual average NER heat values lower than 1 have been obtained in six locations, and values only slightly higher than 1 in another three locations, meaning that a positive heat balance is not feasible there. It should be noted that NER values slightly higher than 1 do not guarantee a positive balance, due to both the fluctuations within the year and the uncertainty of the assumptions and parameters used in the evaluation.

$\mathrm{NER}_{\text {heat }}$ fluctuation within the year is also different in the different locations, resulting quite low in La Coruña and Oviedo, with a SD of 0.14 and 0.16 , respectively, while it is quite high in Seville and Badajoz, with SD of 0.51 and 0.40 , respectively. These differences and variations are attributed to the environmental temperature, which is a parameter that strongly affects the heat balance, and it clearly varies in the different locations and throughout the year. The extent of this fluctuation can be attributed to the annual temperature range, i.e. the difference between the maximum and the minimum average monthly temperature, being as low as $8.8{ }^{\circ} \mathrm{C}$ and 10.8 ${ }^{\circ} \mathrm{C}$ in La Coruña and Oviedo, respectively, and as high as $17.3{ }^{\circ} \mathrm{C}$ and $17.5{ }^{\circ} \mathrm{C}$ in Seville and Badajoz, respectively (AEMET, 2018). 
These results confirm that the climate conditions have a great effect in the energy balance of microalgae-based WWTPs, specially the solar radiation and environmental temperature. Under the assumptions of this study, these conditions resulted crucial for the heat balance. The best results were obtained in Valencia, Badajoz, Seville and Almeria (maximum NER heat 1.32, Seville), while in the rest of locations the heat produced was not enough to cover the heat requirements. In addition, the four locations aforementioned present lower cloudiness $(46,59$, 50 and 25 average rainy days per year in Valencia, Badajoz, Seville and Almeria, respectively) compared to other locations (see Table 1), so that the reduction of solar radiation due to cloudiness would have a minor effect.

\subsection{Sensitivity analysis}

A sensitivity analysis was performed to assess the influence of the parameters: heat transfer coefficient (k), heat recovery efficiency $(\phi)$, specific power consumption of other units (SPCou), and primary settling efficiency $(\eta)$, in the resulting NER values. The annual average NER electricity $_{\text {. }}$ and $N R_{\text {heat }}$ have been obtained with three different values of the analyzed parameters. Results are depicted in pairs of graphs, one for $\mathrm{NER}_{\text {electricity }}$ and another for $\mathrm{NER}_{\text {heat, }}$ as shown in Figures $7-10$, for the parameters $\mathrm{k}, \phi, \mathrm{SPC}_{\mathrm{ou}}$, and $\eta$, respectively.

$\mathrm{NER}_{\text {electricity }}$ is not influenced by $\mathrm{k}$ and $\phi$, as can be observed in figures 7(a) and $8(\mathrm{a})$, due to the fact that these parameters do not take part in the electrical energy balance. The effect of a variation of the $\mathrm{SPC}_{\mathrm{OU}}$ of $25 \%$ on NER electricity is moderate, as shown in Figure 9(a), but the resulting NER electricity values are between 2.0 and 3.0 in all the simulated scenarios. The effect is practically the same in all the geographic locations. The effect of a variation of $\eta$ of $25 \%$ on NER electricity is even smaller than that for SPCou (Figure 10(a)), and the resulting NER electricity are between 2.3 and 2.6 in all the simulated scenarios. Again, the effect is practically the same in all the geographic locations. It indicates that the high values of NER electricity are not sensitive to variations of the analyzed parameters, reducing the uncertainty about the successful results of the energy balance.

Regarding $\mathrm{NER}_{\text {heat }}$, it is slightly affected by a variation of $\mathrm{k}$ of $25 \%$ compared to the initial value, as observable in Figure $7(\mathrm{~b})$, and this small variation is similar in all the geographic locations. However, a $\phi$ variation of $18 \%$ has a moderate effect in the average $\mathrm{NER}_{\text {heat }}$ (Figure $8(\mathrm{~b})$ ), and the degree of variation of $\mathrm{NER}_{\text {heat }}$ is higher in those geographic locations with the highest $\mathrm{NER}_{\text {heat }}$ On the one hand, if $100 \%$ of the heat required in the pretreatment could be recovered for the subsequent codigestion, the resulting $\mathrm{NER}_{\text {heat }}$ would be higher than 1 in all the geographic locations, except Burgos. On the other hand, when $\phi$ is reduced to $70 \%$, NER heat is only slightly higher than 1 in the most favorable locations (Valencia, Badajoz, Seville and Almeria). Regarding the $\mathrm{SPC}_{\mathrm{OU}}$, it has no effect on $\mathrm{NER}_{\text {heat }}$ (Figure 9(b)), as expected since SPC $_{\mathrm{Ou}}$ has no influence on the thermal balance, while $\eta$ has very little effect on it, almost negligible, as observable in Figure 6(b).

These results have been confirmed with the absolute-relative sensitivity functions (see Supplementary Material). 

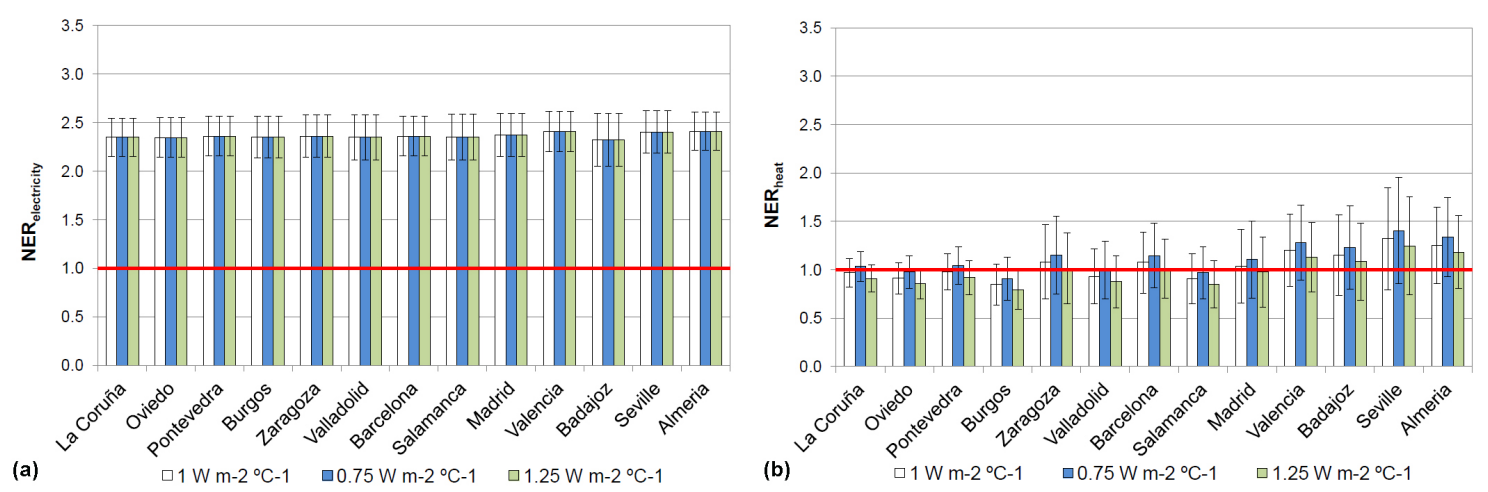

Figure 7. Results of the sensitivity analysis of the heat transfer coefficient $\left(\mathrm{k}, \mathrm{W} \mathrm{m}^{-2}{ }^{\circ} \mathrm{C}^{-1}\right)$ on the (a) $\mathrm{NER}_{\text {electricity }}$ and (b) $\mathrm{NER}_{\text {heat }}$ (annual average $\pm \mathrm{SD}$ ).
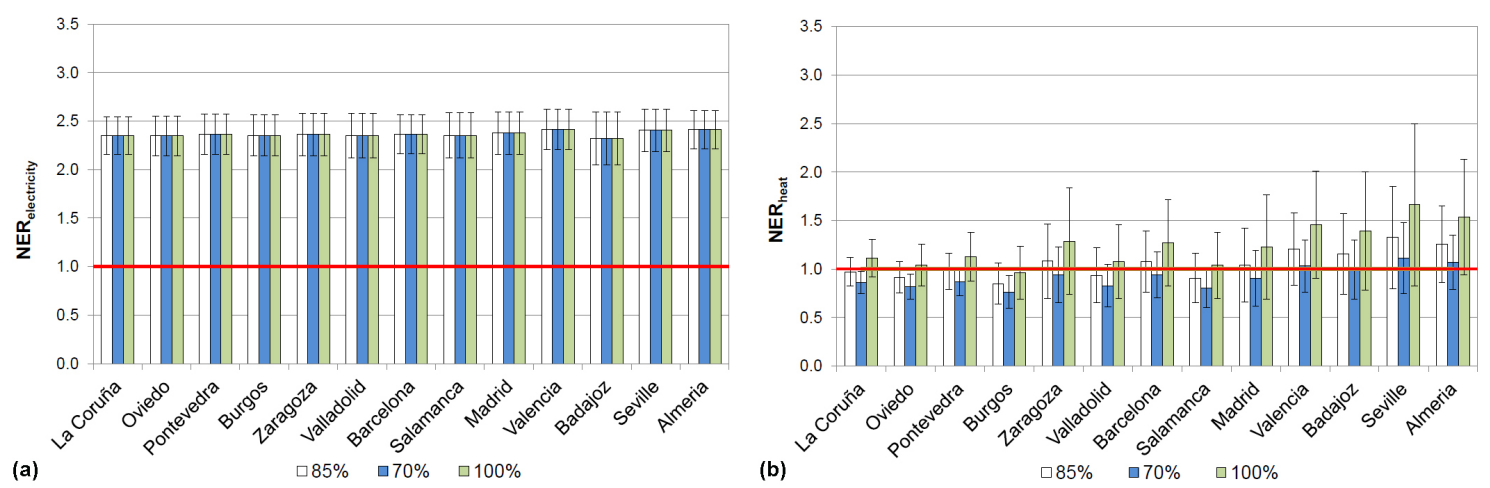

Figure 8 . Results of the sensitivity analysis of the heat recovery efficiency $(\phi, \%)$ on the (a) $\mathrm{NER}_{\text {electricity }}$ and (b) $\mathrm{NER}_{\text {heat }}$ (annual average $\pm \mathrm{SD}$ ).
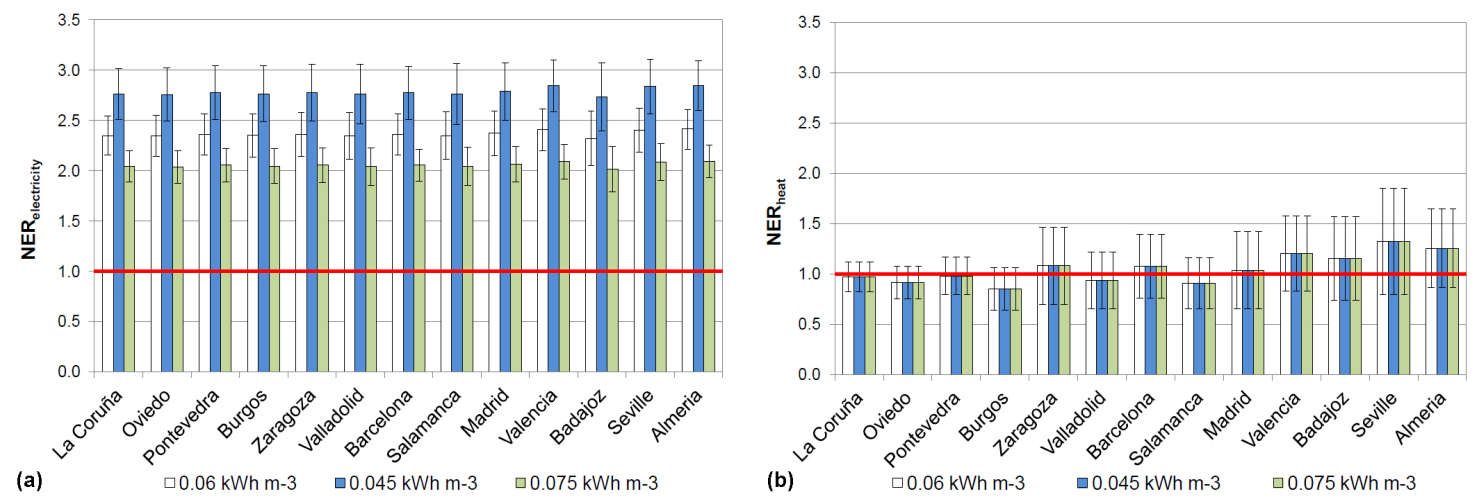

Figure 9. Results of the sensitivity analysis of the specific power consumption of other units $\left(\mathrm{SPC}_{\mathrm{Ou}}, \mathrm{kWh} \mathrm{m}^{-3}\right.$ ) on the (a) NER electricity and (b) $\mathrm{NER}_{\text {heat }}$ (annual average $\pm \mathrm{SD}$ ). 

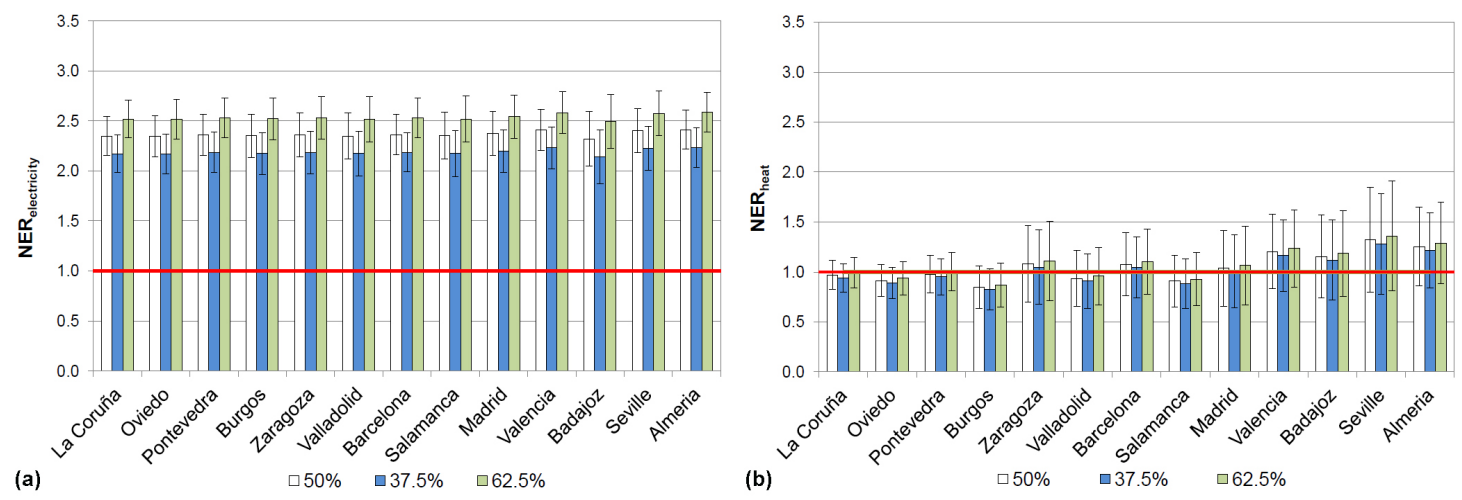

Figure 10. Results of the sensitivity analysis of the primary settling efficiency ( $\eta, \%)$ on the (a) $\mathrm{NER}_{\text {electricity }}$ and (b) $\mathrm{NER}_{\text {heat }}$ (annual average $\pm \mathrm{SD}$ )

\subsection{Monthly energy and heat balance}

Almeria and Seville, the two most favorable locations have been analyzed more in detail regarding the monthly variation and the main elements of the NER electricity and NER heat. The evolution of the NER electricity and NER heat monthly average values in both locations is shown in Figure 11.
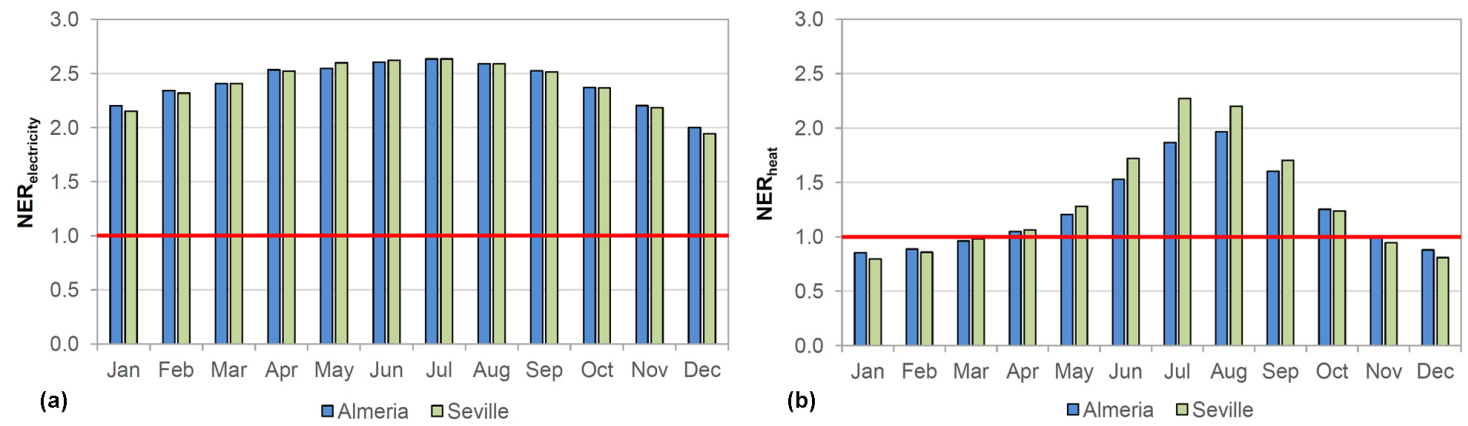

Figure 11. Average monthly net energy ratio (NER) for (a) electricity and (b) heat in Almeria and Seville

The monthly variation of $\mathrm{NER}_{\text {electricity }}$ is quite smooth and similar in both locations. NER electricity $_{\text {. }}$ values higher than 2 are obtained during the whole year, except in December. However, the variation of $\mathrm{NER}_{\text {heat }}$ is more pronounced, with values lower than 1 in November-March and peaks close to 2 in July and August in Almeria, and higher than 2 in Seville.

These results confirm the feasibility of the positive electrical energy balance during the whole year, making it possible that the microalgae-based WWTP becomes an energy producer instead of an energy consumer. However, the heat balance is negative in some periods of the year. This implies the temporary need for an external supplementary heat source, which would only operate when needed. In a different approach, aimed at achieving energy self-sufficiency in the WWTP, it could be considered the possibility of not providing extra heating. Since even the lower values of $\mathrm{NER}_{\text {heat }}$ are close to 1, the digester temperature would not decrease excessively from $35{ }^{\circ} \mathrm{C}$. Further research is needed to assess the methane yield and the overall energy balance under those conditions.

A more detailed description of the main factors influencing the $\mathrm{NER}_{\text {electricity }}$ and $\mathrm{NER}_{\text {heat }}$ is summarized in Table 3. The energy inputs derived from the different elements of the treatment plant are presented together with the energy output obtained from the biogas in a quarterly basis. 


\begin{tabular}{|c|c|c|c|c|c|c|}
\hline & Parameter & Unit & Jan-Mar & Apr-Jun & Jul-Sep & Oct-Dec \\
\hline \multirow[t]{8}{*}{ Almeria } & $E_{\text {input, electricity HRAP }}$ & $\mathrm{kWh} \mathrm{d}^{-1}$ & 26.6 & 17.8 & 17.8 & 26.6 \\
\hline & $\mathrm{E}_{\text {input, electricity } \mathrm{AD}}$ & $\mathrm{kWh} \mathrm{d}^{-1}$ & 35.3 & 35.6 & 35.7 & 34.8 \\
\hline & $\mathrm{E}_{\text {input, electricity other units }}$ & $\mathrm{kWh} \mathrm{d}^{-1}$ & 90.0 & 90.0 & 90.0 & 90.0 \\
\hline & Eutput, electricity & $\mathrm{kWh} \mathrm{d}^{-1}$ & 351.9 & 367.4 & 370.5 & 332.0 \\
\hline & $\mathrm{NER}_{\text {electricity }}$ & & 2.3 & 2.6 & 2.6 & 2.2 \\
\hline & $\mathrm{E}_{\text {input, heat } \mathrm{AD}}$ & $\mathrm{kWh} \mathrm{d}^{-1}$ & 614.2 & 468.1 & 323.3 & 504.2 \\
\hline & $E_{\text {output, heat }}$ & $\mathrm{kWh} \mathrm{d}^{-1}$ & 553.0 & 577.4 & 582.1 & 521.7 \\
\hline & $\mathrm{NER}_{\text {heat }}$ & & 0.9 & 1.3 & 1.8 & 1.0 \\
\hline \multirow[t]{8}{*}{ Seville } & $\mathrm{E}_{\text {input, electricity HRAP }}$ & $\mathrm{kWh} \mathrm{d}^{-1}$ & 26.6 & 17.8 & 17.8 & 26.6 \\
\hline & $\mathrm{E}_{\text {input, electricity } \mathrm{AD}}$ & $\mathrm{kWh} \mathrm{d}^{-1}$ & 35.2 & 35.7 & 35.7 & 34.7 \\
\hline & $E_{\text {input, electricity other units }}$ & $\mathrm{kWh} \mathrm{d}^{-1}$ & 90.0 & 90.0 & 90.0 & 90.0 \\
\hline & Eoutput, electricity & $\mathrm{kWh} \mathrm{d}^{-1}$ & 348.0 & 370.4 & 369.9 & 327.7 \\
\hline & $\mathrm{NER}_{\text {electricity }}$ & & 2.3 & 2.6 & 2.6 & 2.2 \\
\hline & $\mathrm{E}_{\text {input, heat } \mathrm{AD}}$ & $\mathrm{kWh} \mathrm{d}^{-1}$ & 624.5 & 445.4 & 286.4 & 524.8 \\
\hline & $E_{\text {output, heat }}$ & $\mathrm{kWh} \mathrm{d}^{-1}$ & 546.9 & 582.1 & 581.3 & 515.0 \\
\hline & $\mathrm{NER}_{\text {heat }}$ & & 0.9 & 1.4 & 2.1 & 1.0 \\
\hline
\end{tabular}

Table 3. Average seasonal energy assessment of the microalgae-based WWTP in Almeria and Seville.

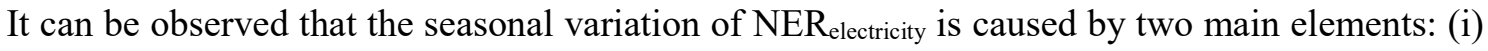
the reduction on HRAPs energy consumption during April to September, when only two HRAPs are in operation; and (ii) the increase in the energy production from biogas in the same period, due to slightly higher biomass availability; being the latter the most noticeable. The electrical energy input ranged from 143 to $152 \mathrm{kWh} \mathrm{d}^{-1}$, and the total energy input (including the energy for heating the anaerobic digester) ranged from 430 to $776 \mathrm{kWh} \mathrm{d}^{-1}$. These are low energy consumptions compared to that of a conventional activated sludge processes. The estimated energy consumption of a conventional medium-sized WWTP treating the wastewater of the same hypothetical population, based on extended aeration activated sludge, without primary sedimentation and without anaerobic digestion of the sludge, is $1,095 \mathrm{kWh} \mathrm{d}^{-1}$. This value has been estimated considering a specific energy consumption of $0.73 \mathrm{kWh} \mathrm{m}^{-3}$ (Ferrer, 2012).

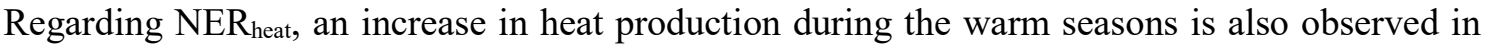
both locations, due to the slightly higher biomass availability. However, the most relevant element causing the seasonal variation of NER $_{\text {heat }}$ is the drastic decrease in the energy required for digestion heating in the warm season compared to the cold. This reduction is due to the higher environmental temperature during the warm season, which is a key point in the heat balance of the proposed WWTP scheme. The variation of the energy requirements for digestion heating is even more pronounced in Seville than in Almeria, which is attributed to the more extreme temperatures. Almeria is a costal location with an annual temperature range of $14.1{ }^{\circ} \mathrm{C}$, whereas Seville is an inland location where such range rises to $17.3{ }^{\circ} \mathrm{C}$ (AEMET, 2018), reaching higher maximum and lower minimum temperatures (see Table 1). 


\section{CONCLUSIONS}

Microalgae-based wastewater treatment coupled with anaerobic codigestion of biomass and primary sludge is a process treating and recovering energy and resources from wastewater, using solar energy simultaneously and leading to an overall energy producing process instead of an energy consuming one. The electrical energy balance was not only neutral but positive in all the analyzed locations, covering the different Spanish latitudes, longitudes and environmental temperatures. Under the assumptions of the present study, the electrical energy balance was similar in all the locations, and fluctuations during the year were not highly noticeable, meaning that the feasibility of the positive energy balance can be achieved during the whole year, in spite of the climatic conditions variations. In addition, the energy balance is not sensitive to variations of the main parameters, reducing the uncertainty about the results.

However, the heat balance resulted closer to the neutral footprint, with noticeable differences between the different locations and fluctuations during the year. A positive heat balance is not feasible in all the locations, being the solar radiation and the environmental temperature determining factors to achieve this aim.

Analyzing more in detail the most favorable locations (Almeria and Seville), it was confirmed the feasibility of a positive electrical energy balance, while the heat balance resulted negative, but not far to the neutrality, in the cold season. The energy input required for digestion heating is the most significant element affecting the heat balance, and its variation in the different seasons is pronounced, especially in locations with a high annual temperature range. The environmental temperature and its variation during the year is a key variable in the heat balance of the proposed WWTP scheme.

\section{Acknowledgments}

R. Díez-Montero, M. J. García-Galán and E. Uggetti would like to thank the Spanish Ministry of Industry and Economy for their research grants [FJCI-2016-30997, FJCI-2014-22767 and IJCI-2014-21594, respectively]. 


\section{References}

Acién, F.G., Gómez-Serrano, C., Morales-Amaral, M.M., Fernández-Sevilla, J.M., MolinaGrima, E., 2016. Wastewater treatment using microalgae: how realistic a contribution might it be to significant urban wastewater treatment? Appl. Microbiol. Biotechnol. 100, 9013-9022. https://doi.org/10.1007/s00253-016-7835-7

AEMET, 2018. Agencia Estatal de Meteorología. Gobierno de España [WWW Document]. URL http://www.aemet.es/ (accessed 1.15.18).

Chisti, Y., 2016. Large-Scale production of algal biomass: Raceway ponds, in: Bux, F., Chisti, Y. (Eds.), Algae Biotechnology. Springer, pp. 21-40. https://doi.org/10.1007/978-3-31912334-9

Chisti, Y., 2007. Biodiesel from microalgae. Biotechnol. Adv. 25, 294-306. https://doi.org/10.1016/j.biotechadv.2007.02.001

Climaenmapas, 2018. Mapas y gráficos climatológicos [WWW Document]. URL climaenmapas.blogspot.com.es (accessed 1.15.18).

Craggs, R., Park, J., Heubeck, S., Sutherland, D., 2014. High rate algal pond systems for lowenergy wastewater treatment, nutrient recovery and energy production. New Zeal. J. Bot. 52, 60-73. https://doi.org/10.1080/0028825X.2013.861855

Dodd, J.C., 1986. Elements of pond design and construction, in: Richmond, A. (Ed.), CRC Handbook of Microalgal Mass Culture. CRC Press, Boca Raton, FL, pp. 265-283.

European Union, 2000. Directive 2000/60/EC of the European Parliament and of the Council of 23 October 2000 establishing a framework for Community action in the field of water policy.

European Union, 1991. Council Directive 91/271/EEC of 21 May 1991 concerning urban wastewater treatment.

Ferrer, J., 2012. Sistemas de control y optimización del consumo energético en EDAR, in: XXX Curso Tratamiento de Aguas Residuales y Explotación de Estaciones Depuradoras. Centro de Estudios y Experimentación de Obras Públicas (CEDEX), Gobierno de España, Madrid.

García, J., Green, B.F., Lundquist, T., Mujeriego, R., Hernández-Mariné, M., Oswald, W.J., 2006. Long term diurnal variations in contaminant removal in high rate ponds treating urban wastewater. Bioresour. Technol. 97, 1709-1715. https://doi.org/10.1016/j.biortech.2005.07.019

García, J., Mujeriego, R., Hernandez-Marine, M., 2000. High rate algal pond operating strategies for urban wastewater nitrogen removal. Appl. Phycol. 12, 331-339. https://doi.org/10.1023/a:1008146421368

Gujer, W., Henze, M., Mino, T., Van Loosdrecht, M., 1999. Activated Sludge Model No. 3. Water Sci. Technol. 39, 183-193. https://doi.org/10.1016/S0273-1223(98)00785-9

Gutiérrez, R., Ferrer, I., González-Molina, A., Salvadó, H., García, J., Uggetti, E., 2016. Microalgae recycling improves biomass recovery from wastewater treatment high rate algal ponds. Water Res. 106, 539-549. https://doi.org/10.1016/j.watres.2016.10.039

Hoffmann, J.P., 1998. Wastewater treatment with suspended and nonsuspended algae. J. Phycol. https://doi.org/10.1046/j.1529-8817.1998.340757.x

Lu, J., Gavala, H.N., Skiadas, I. V., Mladenovska, Z., Ahring, B.K., 2008. Improving anaerobic sewage sludge digestion by implementation of a hyper-thermophilic prehydrolysis step. J. Environ. Manage. 88, 881-889. https://doi.org/10.1016/j.jenvman.2007.04.020

Lundquist, T.J., Woertz, I.C., Quinn, N.W.T., Benemann, J.R., 2010. A realistic technology and engineering assessment of algal biofuel production, Energy Biosciences Institute. https://doi.org/10.1556/1848.2015.6.1.6

Oswald, W.J., 1988. Large-scale algal culture systems (engineering concepts), in: Borowitzka, M.A., Borowitzka, L.J. (Eds.), Micro-Algal Biotechnology. Cambridge University Press, Cambridge, pp. 357-394. https://doi.org/10.1016/0014-5793(88)80268-0

Passos, F., Ferrer, I., 2014. Microalgae conversion to biogas: Thermal pretreatment contribution on net energy production. Environ. Sci. Technol. 48, 7171-7178. 
https://doi.org/10.1021/es500982v

Passos, F., Gutiérrez, R., Uggetti, E., Garfí, M., García, J., Ferrer, I., 2017. Towards energy neutral microalgae-based wastewater treatment plants. Algal Res. 28, 235-243. https://doi.org/10.1016/j.algal.2017.11.006

Solé, M., Passos, F., Garfi, M., Ferrer, I., 2015. Microalgae and primary sludge co-digestion: effect of thermal pretreatment, energy balance and digestate characteristics, in: 14th World Congress Anaerobic Digestion. Viña del Mar, Chile.

Solimeno, A., 2017. Numerical modelling of microalgae systems for wastewater treatment. Universitat Politècnica de Catalunya.

Solimeno, A., Gabriel, F., García, J., 2017a. Mechanistic model for design, analysis, operation and control of microalgae cultures: Calibration and application to tubular photobioreactors. Algal Res. 21, 236-246. https://doi.org/10.1016/j.algal.2016.11.023

Solimeno, A., Parker, L., Lundquist, T., García, J., 2017b. Integral microalgae-bacteria model (BIO_ALGAE): Application to wastewater high rate algal ponds. Sci. Total Environ. 601602, 646-657. https://doi.org/10.1016/j.scitotenv.2017.05.215

Solimeno, A., Samsó, R., García, J., 2016. Parameter sensitivity analysis of a mechanistic model to simulate microalgae growth. Algal Res. 15, 217-223. https://doi.org/10.1016/j.algal.2016.02.027

Solimeno, A., Samsó, R., Uggetti, E., Sialve, B., Steyer, J.P., Gabarró, A., García, J., 2015. New mechanistic model to simulate microalgae growth. Algal Res. 12, 350-358. https://doi.org/10.1016/j.algal.2015.09.008

Suganya, T., Varman, M., Masjuki, H.H., Renganathan, S., 2016. Macroalgae and microalgae as a potential source for commercial applications along with biofuels production: A biorefinery approach. Renew. Sustain. Energy Rev. 55, 909-941. https://doi.org/10.1016/j.rser.2015.11.026

Sutherland, D.L., Turnbull, M.H., Craggs, R.J., 2014. Increased pond depth improves algal productivity and nutrient removal in wastewater treatment high rate algal ponds. Water Res. 53, 271-281. https://doi.org/10.1016/j.watres.2014.01.025

Tchobanoglous, G., Burton, F.L., Stensel, H.D., 2003. Wastewater engineering: treatment and reuse, McGraw-Hill. https://doi.org/10.1016/0309-1708(80)90067-6

Uggetti, E., Passos, F., Solé, M., Garfí, M., Ferrer, I., 2017. Recent Achievements in the Production of Biogas from Microalgae. Waste and Biomass Valorization 8, 129-139. https://doi.org/10.1007/s12649-016-9604-3 